\title{
Growth Performance, Carcass Quality, Visceral Organs and Intestinal Histology in Broilers Fed Dietary Dried Fermented Ginger and/or Fermented Corncob Powder
}

\author{
Duddoa Khonyoung1,2, Janjira Sittiya ${ }^{1,3}$, Koh-en Yamauchi ${ }^{*}$ \\ ${ }^{1}$ Laboratory of Animal Science, Faculty of Agriculture, Kagawa University, Kagawa-ken, Japan \\ ${ }^{2}$ Faculty of Animal Science and Technology, Maejo University, Phrae Campus, Phrae, Thailand \\ ${ }^{3}$ Faculty of Animal Sciences and Agricultural Technology, Silpakorn University, Phetchaburi, Thailand \\ Email: *yamauchi@ag.kagawa-u.ac.jp
}

How to cite this paper: Khonyoung, D., Sittiya, J. and Yamauchi, K. (2017) Growth Performance, Carcass Quality, Visceral Organs and Intestinal Histology in Broilers Fed Dietary Dried Fermented Ginger and/ or Fermented Corncob Powder. Food and Nutrition Sciences, 8, 565-577.

https://doi.org/10.4236/fns.2017.85039

Received: March 20, 2017

Accepted: May 21, 2017

Published: May 24, 2017

Copyright (c) 2017 by authors and Scientific Research Publishing Inc. This work is licensed under the Creative Commons Attribution International License (CC BY 4.0).

http://creativecommons.org/licenses/by/4.0/

\begin{abstract}
To determine whether dried fermented ginger (DFG), fermented with Japanese mugwort silage juice, could be replaced by fermented corncob powder (FCP) as a of feed ingredient source without significant body weight decrease or damage to visceral organs (using gross anatomical observation), to intestinal villi (using light microscopy), or to the epithelial cells on the villus apical surface (using scanning electron microscopy) the following investigation was performed. Sixty-four male broilers were allotted to 4 groups: a basal diet group (control group), and basal diet groups with DFG at a level of $50 \mathrm{ppm}$; with DFG at $50 \mathrm{ppm}$ and FCP at $250 \mathrm{ppm}$ (50 ppm DFG + $250 \mathrm{ppm} \mathrm{FCP}$ group); and with FCP at a level of 500 ppm (500 ppm FCP group). Feed intake, body weight gain, feed efficiency, carcass quality, small intestinal length and weight, and visceral organ weight were not different among groups. Furthermore, regarding intestinal villus height, villus area and crypt depth, a significant difference was not found among the groups. When these values of the control were expressed as an index of 100, the duodenal villus height of the 50 ppm DFG + 250 ppm FCP group and the 500 ppm FCP group were 114 and 119 , respectively. The duodenal villus area of the $50 \mathrm{ppm} D F G+250 \mathrm{ppm}$ FCP group and the 500 ppm FCP group were 125 and 158, respectively. These villus heights and areas are thought to be activated. On the epithelial cells on the villus apical surface in the duodenum and jejunum, the $50 \mathrm{ppm}$ DFG + 250 ppm FCP group had protuberated cells into the intestinal lumen and deeper cells at the sites of recently exfoliated cells, suggesting that these cells are activated. The present results indicate that small amounts of fermented corncob powder can be used as a feed supplement when mixed with fer-
\end{abstract}


mented ginger powder, due to the synergy between the two ingredients, resulting in a $6 \%$ increase in body weight gain.

\section{Keywords}

Fermented Ginger and Corncob, Growth Performance, Carcass Quality, Intestine, Light and Scanning Electron Microscpy

\section{Introduction}

Feed represents the largest cost associated with poultry production, and the major source of feed ingredients is corn. However, corn ethanol production has grown rapidly in the last decade, subsequent to corn's first being employed in biogas production [1] from the 1970s in the USA; decreasing corn yields and the high demand for ethanol production have led to increased prices for corn. Consequently, for some time, some poultry farmers have been focusing on reducing feed costs without negative effects on growth performance by adding various dietary supplements. Corncob, as a by-product of corn crops, is produced in very large amounts from corn manufactory, due to the fact that $40 \%-50 \%$ of a corn crop is comprised of corncob, the fibers of which are $30 \%-40 \%$ cellulose, $20 \%$ $36 \%$ hemicellulose, $16 \%$ lignin, and $8 \%$ other materials [2]. Consequently, most corncobs are not used effectively but are dumped into fields, resulting in environmental contamination due to the occurrence of mycotoxins such as aflatoxin. To increase of the economic value of corncobs, efforts should be made to ferment it for use as a poultry feed supplement.

Japanese mugwort silage juice (JMS) liquid includes natural microorganisms, such as lactic acid bacteria, yeast fungus, photosynthetic bacteria, ray-fungus, hyperthermal bacteria, and Aspergillus and Bacillus subtilis [3]. When this JMS was mixed with dried ground ginger (dried fermented ginger; DFG), the production performance of layer chickens [3] and body weight gain in broilers [4] increased due to the hypertrophy of intestinal villi and epithelial cells. However, as ginger has a high purchase price, the use of agricultural by-products other than ginger was necessary. As described above, corncob is cheap and discarded without being effectively used; thus, it might be a useful and economical alternative replacement for ginger. The corncob itself is very difficult to use as a feed ingredient due to its high fiber content. In fact, the daily body weight gain decreased in pigs when their diets were supplemented with an increased level of corncob, because the high fiber in the corncob is resistant to the pig's digestive enzymes [5]. Consequently, corncob powder was fermented with waste JMS after DFG production. This fermented corncob powder (FCP) can be used as a broiler feed ingredient if measured values of birds fed dietary FCP do not show a significant decrease in growth performance compared to those in the control, and intestinal villi demonstrate no histological damage.

The aim of the present study was to determine whether ginger could be re- 
placed by corncob as a source of feed ingredient to economize feed costs without a significant decrease in body weight. The following observations were performed: the presence or absence of damage on visceral organs using gross anatomical observation; on intestinal villi using light microscopy; and on the epithelial cells on the villus apical surface using scanning electron microscopy.

\section{Materials and Methods}

\subsection{Preparation of DFG, JMS and FCP}

Japanese mugwort plants were harvested and ensiled at room temperature to get JMS. Grounded ginger by-product was added into the JMS solution, kept under anaerobic conditions at room temperature for $4-5 \mathrm{~d}$, dried in a hot air oven at $50^{\circ} \mathrm{C}$ for $1-2 \mathrm{~d}$ and again ground for finally making DFG [3] [4]. On the other hand, FCP was made as follows: sliced corncob was soaked into the remaining JMS after soaking ginger for DFG dried up, and then milled.

\subsection{Birds, Diet and Housing}

Newly hatched male broilers (Marshall Chunky) were obtained from a commercial hatchery, and conventional starter $(1-21 \mathrm{~d})$ and finisher $(22-49 \mathrm{~d})$ diets were used as basal diets (Table 1). At $7 \mathrm{~d}$ of age, birds with similar weights were allotted to 4 groups: a basal diet group (control group) and basal diet with DFG (Table 2) at $50 \mathrm{ppm}$ level (50 ppm DFG group), with DFG at $50 \mathrm{ppm}$ and FCP at $250 \mathrm{ppm}$ (50 ppm DFG + $250 \mathrm{ppm}$ FCP group) and with FCP at 500 ppmlevel (500 ppm FCP group). Each group had 4 replicates of 4 chickens. The chicks were raised in floor pens in a room under natural light in the day and continuous fluorescent lighting at night during the experimental period. Feed and water were available ad libitum throughout the experimental period. Feed intake and body weight were monitored weekly.

\subsection{Tissue Sampling}

At $49 \mathrm{~d}$ of age, 4 birds per group from each replicate were dissipated. The entire small intestine was then removed and processed in a mixture of $3 \%$ glutaraldehyde and $4 \%$ paraformaldehyde fixative solution in $0.1 M$ cacodylate buffer ( $\mathrm{pH}$ 7.4). The same fixative solution was additionally infused into the intestinal lumen at low pressure. The duodenum extended from the gizzard to the pancreatic and bile ducts; the jejunum extended from the bile ducts to Meckel's diverticulum, and the ileum from the diverticulum to the ileocecal junction. A $2-\mathrm{cm}$ length of the middle part of each intestinal segment was excised and prepared for light and scanning electron microscopy (SM). Each segment was gently flushed with $0.1 \mathrm{M}$ phosphate-buffered saline ( $\mathrm{pH}$ 7.4) to remove the intestinal contents.

\subsection{Scanning Electron Microscopy}

Samples for SM were cut lengthwise along the line of the mesentery, opened, and flushed with $0.1 M$ phosphate buffered saline ( $\mathrm{pH}$ 7.4). These samples were 
Table 1. Composition of the basal diets (g/kg diet).

\begin{tabular}{|c|c|c|}
\hline Item & Starter 1 to $21 \mathrm{~d}$ & Finisher 22 to $49 \mathrm{~d}$ \\
\hline \multicolumn{3}{|l|}{ Ingredient } \\
\hline Corn & 590 & 420 \\
\hline Milo & 20 & 220.0 \\
\hline Corn gluten meal & 290 & - \\
\hline Soybean meal (45\%CP) & - & 270.0 \\
\hline Rice bran & 23.0 & 52.0 \\
\hline Fish meal (57\%CP) & 70.0 & 30.0 \\
\hline Tallow & 5.0 & 6.0 \\
\hline Vitamin/mineral premix ${ }^{1}$ & 2.0 & 2.0 \\
\hline Total (g) & 1000.00 & 1000.00 \\
\hline \multicolumn{3}{|l|}{ Calculated composition } \\
\hline Crude protein (\%) & 22.00 & 18.00 \\
\hline $\mathrm{ME}(\mathrm{kcal} / \mathrm{kg})$ & 3,050 & 3,250 \\
\hline Crude fat (\%) & 4 & 6 \\
\hline Crude fiber (\%) & 4 & 4 \\
\hline Crude ash (\%) & 7 & 7 \\
\hline Calcium (\%) & 0.8 & 0.7 \\
\hline Available Phosphorus (\%) & 0.5 & 0.45 \\
\hline
\end{tabular}

${ }^{1}$ Vitamin and mineral premix include per kg of diet: retinyl acetate, $2880 \mu \mathrm{g}$; cholecalciferol, $48 \mu \mathrm{g}$; DL- $\alpha$ tocopherol acetate, $35 \mathrm{mg}$; menadione, $2.6 \mathrm{mg}$; thiamine, $5.8 \mathrm{mg}$; riboflavin, $7.3 \mathrm{mg}$; pyridoxine, $10.4 \mathrm{mg}$; cobalamine, $12.6 \mu \mathrm{g}$; biotin, $0.2 \mathrm{mg}$; folic acid, $1.0 \mathrm{mg}$; pantothenic acid, $16.1 \mathrm{mg}$; niacin, $69.1 \mathrm{mg}$; choline, $1400 \mathrm{mg}$; manganese, $92.4 \mathrm{mg}$; zinc, $79.9 \mathrm{mg}$; copper, $12.8 \mathrm{mg}$.

Table 2. Proximate composition of dried fermented ginger (DFG) and fermented corncob powder (FCP).

\begin{tabular}{ccc}
\hline Items & DFG & FCP \\
\hline Dry matter & 87.44 & \\
Crude protein & 7.29 & \\
Crude fat & 6.51 & \\
Crude fiber & 22.10 \\
Crude ash & 13.40 \\
Calcium & 0.46 \\
Phosphorus & 0.84 & \\
Gross energy (kcal/kg) & 3908 & \\
\hline
\end{tabular}

All parameters of DFG samples were determined in triplicate (Incharoen and Yamauchi, 2009; Incharoenet et al. 2010).

pinned flat to prevent curling and fix them vertically with the mucosal face downward in a mixture of $3 \%$ glutaraldehyde and $4 \%$ paraformaldehyde in 0.1 $M$ cacodylate buffer ( $\mathrm{pH} 7.4$ ) at room temperature for $1 \mathrm{~h}$. The tissue block was 
cut into $5 \times 6 \mathrm{~mm}$ square and fixed for an additional $1 \mathrm{~h}$. The pieces were rinsed with $0.1 M$ sodium cacodylate buffer ( $\mathrm{pH} 7.4$ ) and post-fixed with $1 \%$ osmiumtetroxide in the ice-cold buffer for $2 \mathrm{~h}$. Then, these pieces were washed in deionizing distilled water, stored in $45 \%$ ethanol for $24 \mathrm{~h}$, and kept in $70 \%$ ethanol. Just before drying, specimens were transferred to $80 \%, 90 \%$ and $100 \%$ ethanol solution (120, 60 and $15 \mathrm{~min}$, respectively) and submerged in t-butyl alcohol (15 min; 3 times). Afterwards, these specimens were freeze-dried (Hitachi ES-2030 freeze dryer, Hitachi Ltd., Tokyo, Japan). The freeze-dried specimens were mounted on aluminum stubs with electrically conducting carbon paste, coated (E-1030 ion sputters, Hitachi Ltd., Tokyo, Japan), and viewed under a scanning electron microscope (Hitachi S-4300SE/N, Hitachi Ltd., Tokyo, Japan) at eight $\mathrm{kV}$. Morphological alterations of the epithelial cells on the villus apical surface were compared.

\subsection{Light Microscopy}

After keep in Bouin's solution, the intestinal segments were embedded in paraplast wax, cut into $4-\mu \mathrm{m}$ transverse sections, and stained with hematoxylin-eosin. Eight sections per intestinal segment per bird were used to measure villus height, villus area and crypt depth by an image analyzer (Nis-Element D, Nikon Co., Tokyo, Japan). The 48 villi per bird were randomly chosen to measure villus height, from the villus tip to the base. And the 4 mean villus heights from 4 birds were expressed as a mean villus height for 1 group. The villus area was calculated from the villus height, basal width, and apical width [6]. Likewise, the longest crypt was chosen, and measured its length as crypt depth.

\subsection{Gross Anatomical Observations of Visceral Organs}

At $50 \mathrm{~d}$ of age, 8 birds in each group were used to measure carcass quality, small intestinal length and weight, and visceral organ weight. After decapitation, the entirety of the visceral organs was removed. The weights of the visceral organs, proventriculus, gizzard, and liver were measured. The whole small intestine, from the gizzard to the large intestine, was removed. The weights and lengths of duodenum, jejunum, and ileum were recorded.

\subsection{Data Collection and Statistical Analyses}

Growth performance such as body weight and feed intake were measured weekly to calculate body weight gain, and feed efficiency was calculated from body weight gain per feed intake. Growth performance, carcass percentage, and light microscopic parameters were analyzed by a one-way analysis of variance (ANOVA). Significance was determined at $\mathrm{p}<0.05$, using Duncan's multiple range tests to compare differences among groups.

The experiment was performed in accordance with the guidelines and rules of care and use of laboratory animal experimentation established by Kagawa University in Japan. The experimental procedure was approved by the Animal Research Committee of the Kagawa University, Japan. 


\section{Results}

\subsection{Growth Performance}

Feed intake, body weight gain, and feed efficiency did not differ among the groups (Table 3).

\subsection{Carcass Quality, Visceral Organ Weight and Small Intestinal Length and Weight}

Compared with the control, the percentage weights of carcass, thigh (drumsticks and thighs), breast, wing and abdominal fat did not differ among the experimental groups (Table 4). The relative length of the duodenum, jejunum, ileum, and total small intestinal length to $100 \mathrm{~g}$ body weight did not differ. The relative weights of total visceral organs, gizzard, proventriculus, live, duodenum, jejunum, and ileum to $100 \mathrm{~g}$ of body weight also did not differ.

\subsection{Histological Analysis of Light Microscopic Parameters}

Compared with the control, the intestinal villus height, villus area, and crypt depth in each intestinal segment of the experimental groups did not differ (Table 5). The intestinal villus height and villus area in each intestinal segment of the 500 ppm groups FCP had numerically higher values than the control, although they were not significantly different (Table 5).

\subsection{Scanning Electron Microscopic Observations of Epithelial Cells on the Villus Apical Surface}

Although the majority of epithelial cells on the duodenal villus apical surface of the control group were flat (small arrows in Figure 1(a)), some cells (large arrow) protuberated into the intestinal lumen. The villus apical surface of the 50 ppm DFG group was distributed with only flat cells (small arrows in Figure $1(\mathrm{~b}))$. The majority of the cells of the $50 \mathrm{ppm} \mathrm{DFG}+250 \mathrm{ppm}$ FCP group were protuberated (large arrows in Figure 1(c)). The apical surface of the $500 \mathrm{ppm}$ FCP group (Figure 1(d)) had a mix of flat cells (small arrows), protuberated cells (large arrows), and deeper cells at the sites of recently exfoliated cells (arrows with D). On the jejunal villus apical surface of the control (Figure 2(a)), flat cells were found (small arrows). The $50 \mathrm{ppm} \mathrm{DFG} \mathrm{group} \mathrm{(Figure} \mathrm{2(b))} \mathrm{had}$

Table 3. Effect of dietary basal diet with 0 (Control), 50 ppm DFG, 50 ppm DFG +250 ppm FCP and 500 ppm FCP on feed intake, body weight gain, feed efficiency and ratio for 100 index of control in broilers during $7-49$ days $($ Mean \pm SEM, $n=4)$

\begin{tabular}{cccccc}
\hline Items & Control & 50ppm DFG & 50 ppm DFG + 250 ppm FCP & 500 ppm FCP & p-value \\
\hline Body weight gain (g) & $3102.39 \pm 466.41$ & $3217.13 \pm 156.68$ & $3301.94 \pm 209.45$ & $3115.37 \pm 172$. & 0.725 \\
Ratio for 100 index of control & 100 & 104 & 106 & 100 & 100 \\
Feed intake (g) & $5952.08 \pm 465.31$ & $5964.82 \pm 401.23$ & $6090.71 \pm 133.38$ & $5822.68 \pm 621.86$ \\
Ratio for 100 index of control & 100 & 100 & 102 & 98 & 0.863 \\
Feed efficiency & $0.52 \pm 0.05$ & $0.54 \pm 0.01$ & $0.54 \pm 0.04$ & $0.54 \pm 0.04$ & 0.851 \\
Ratio for 100 index of control & 100 & 104 & 104 & 104 \\
\hline
\end{tabular}

DFG; dried fermented ginger, FCP; fermented corncob powder. 
Table 4. Carcass quality (upper, lower $=$ ratio for 100 index of control) in broilers fed dietary basal diet with 0 (Control), 50 ppm DFG, 50 ppm DFG +250 ppm FCP and 500 ppm FCP at 49 days (Mean \pm SEM, $\mathrm{n}=8$ ).

\begin{tabular}{|c|c|c|c|c|c|}
\hline Items & Control & 50 ppm DFG & $\begin{array}{c}50 \mathrm{ppm} \mathrm{DFG}+250 \\
\text { ppm FCP }\end{array}$ & 500 ppm FCP & $\mathrm{p}$-value \\
\hline \multirow{2}{*}{ Carcass (\%) } & $81.653 \pm 1.530$ & $81.023 \pm 1.551$ & $82.676 \pm 1.955$ & $82.657 \pm 0.984$ & \multirow{2}{*}{0.111} \\
\hline & 100 & 9999 & 101 & 101 & \\
\hline $\begin{array}{c}\text { Thigh } \\
\text { (drumsticks and thighs) } \\
(\%)\end{array}$ & $\begin{array}{c}7.802 \pm 0.386 \\
100\end{array}$ & $\begin{array}{c}7.549 \pm 0.472 \\
97\end{array}$ & $\begin{array}{c}7.951 \pm 0.650 \\
102\end{array}$ & $\begin{array}{c}7.502 \pm 0.700 \\
96\end{array}$ & 0.355 \\
\hline Breast (\%) & $\begin{array}{c}19.590 \pm 1.121 \\
100\end{array}$ & $\begin{array}{c}20.995 \pm 1.702 \\
107\end{array}$ & $\begin{array}{c}20.407 \pm 1.113 \\
104\end{array}$ & $\begin{array}{c}21.124 \pm 1.557 \\
108\end{array}$ & 0.135 \\
\hline Wing (\%) & $\begin{array}{c}21.775 \pm 1.426 \\
100\end{array}$ & $\begin{array}{c}21.493 \pm 1.878 \\
99\end{array}$ & $\begin{array}{c}22.427 \pm 1.166 \\
103\end{array}$ & $\begin{array}{c}22.482 \pm 2.115 \\
103\end{array}$ & 0.578 \\
\hline Abdominal fat (\%) & $\begin{array}{c}1.657 \pm 0.459 \\
100\end{array}$ & $\begin{array}{c}1.445 \pm 0.396 \\
87\end{array}$ & $\begin{array}{c}1.481 \pm 0.305 \\
89\end{array}$ & $\begin{array}{c}1.452 \pm 0.527 \\
88\end{array}$ & 0.730 \\
\hline \multicolumn{6}{|l|}{ Length, $\mathrm{cm} / 100 \mathrm{~g} \mathrm{BW}$} \\
\hline Duodenum & $\begin{array}{c}0.973 \pm 0.224 \\
100\end{array}$ & $\begin{array}{c}1.019 \pm 0.171 \\
105\end{array}$ & $\begin{array}{c}0.974 \pm 0.768 \\
100\end{array}$ & $\begin{array}{c}1.024 \pm 0.200 \\
105\end{array}$ & 0.897 \\
\hline Jejunum & $\begin{array}{c}2.599 \pm 0.516 \\
100\end{array}$ & $\begin{array}{c}2.584 \pm 0.504 \\
99\end{array}$ & $\begin{array}{c}2.393 \pm 0.188 \\
92\end{array}$ & $\begin{array}{c}2.598 \pm 0.375 \\
100\end{array}$ & 0.710 \\
\hline Ileum & $\begin{array}{c}2.571 \pm 0.541 \\
100\end{array}$ & $\begin{array}{c}2.665 \pm 0.468 \\
104\end{array}$ & $\begin{array}{c}2.550 \pm 0.313 \\
99\end{array}$ & $\begin{array}{c}2.623 \pm 0.383 \\
102\end{array}$ & 0.951 \\
\hline $\begin{array}{c}\text { Total small intestinal } \\
\text { length }\end{array}$ & $\begin{array}{c}6.143 \pm 1.234 \\
100\end{array}$ & $\begin{array}{c}6.268 \pm 1.095 \\
102\end{array}$ & $\begin{array}{c}5.917 \pm 0.494 \\
96\end{array}$ & $\begin{array}{c}6.245 \pm 0.792 \\
102\end{array}$ & 0.876 \\
\hline \multicolumn{6}{|l|}{ Weight (g/100 g BW) } \\
\hline Total visceral organ & $\begin{array}{c}12.944 \pm 1.362 \\
100\end{array}$ & $\begin{array}{c}13.033 \pm 1.280 \\
101\end{array}$ & $\begin{array}{c}11.606 \pm 1.747 \\
90\end{array}$ & $\begin{array}{c}11.973 \pm 0.618 \\
92\end{array}$ & 0.097 \\
\hline Gizzard & $\begin{array}{c}1.239 \pm 0.110 \\
100\end{array}$ & $\begin{array}{c}1.295 \pm 0.245 \\
105\end{array}$ & $\begin{array}{c}1.209 \pm 0.124 \\
98\end{array}$ & $\begin{array}{c}1.222 \pm 1.822 \\
99\end{array}$ & 0.767 \\
\hline Proventriculus & $\begin{array}{c}0.307 \pm 0.049 \\
100\end{array}$ & $\begin{array}{c}0.303 \pm 0.053 \\
99\end{array}$ & $\begin{array}{c}0.304 \pm 0.037 \\
99\end{array}$ & $\begin{array}{c}0.245 \pm 0.110 \\
80\end{array}$ & 0.220 \\
\hline Liver & $\begin{array}{c}2.065 \pm 0.332 \\
100\end{array}$ & $\begin{array}{c}1.999 \pm 0.294 \\
97\end{array}$ & $\begin{array}{c}1.927 \pm 0.253 \\
93\end{array}$ & $\begin{array}{c}1.901 \pm 0.273 \\
92\end{array}$ & 0.671 \\
\hline Duodenum & $\begin{array}{c}0.566 \pm 0.092 \\
100\end{array}$ & $\begin{array}{c}0.551 \pm 0.082 \\
97\end{array}$ & $\begin{array}{c}0.599 \pm 0.103 \\
106\end{array}$ & $\begin{array}{c}0.581 \pm 0.126 \\
103\end{array}$ & 0.807 \\
\hline Jejunum & $\begin{array}{c}1.291 \pm 0.197 \\
100\end{array}$ & $\begin{array}{c}1.228 \pm 0.231 \\
95\end{array}$ & $\begin{array}{c}1.234 \pm 0.125 \\
96\end{array}$ & $\begin{array}{c}1.295 \pm 0.194 \\
100\end{array}$ & 0.836 \\
\hline Ileum & $\begin{array}{c}0.945 \pm 0.167 \\
100\end{array}$ & $\begin{array}{c}1.019 \pm 0.105 \\
108\end{array}$ & $\begin{array}{c}0.971 \pm 0.109 \\
103\end{array}$ & $\begin{array}{c}0.946 \pm 0.137 \\
100\end{array}$ & 0.645 \\
\hline
\end{tabular}

DFG; dried fermented ginger, FCP; fermented corncob powder.

flat cells (small arrow) and deeper cells at the sites of recently exfoliated cells (arrows with D). The 50 ppm DFG +250 ppm FCP (Figure 2(c)) had faintly protuberated cells (large arrows) and deeper cells at the sites of recently exfoliated cells (arrows with D). On the villus apical surface of the $500 \mathrm{ppm}$ FCP group (Figure 2(d)), flat cells (small arrows), faintly protuberated cells (large arrow), and deeper cells at the sites of recently exfoliated cells (arrows with D) were found. All of the epithelial cells on the ileal villus apical surface of the control group (Figure 3(a)) protuberated into the intestinal lumen (large arrows). The epithelial cells of the $50 \mathrm{ppm}$ DFG (Figure 3(b)), $50 \mathrm{ppm} \mathrm{DFG}+250 \mathrm{ppm}$ FCP (Figure 3(c)) and 500 ppm FCP (Figure 3(d)) groups were flat cells (small arrows). 
Table 5. Light microscopic parameter in broilers fed dietary basal diet with 0 (Control), 50 ppm DFG, 50 ppm DFG +250 ppm FCP and 500 ppm FCP at 49 days (Mean \pm SEM, $\mathrm{n}=4)$.

\begin{tabular}{|c|c|c|c|c|c|}
\hline Item & Control & 50 ppm DFG & $\begin{array}{c}50 \mathrm{ppm} \text { DFG + } \\
250 \mathrm{ppm} \text { FCP }\end{array}$ & 500 ppm FCP & $\mathrm{P}$-value \\
\hline \multicolumn{6}{|l|}{ Duodenum } \\
\hline Villus height & $\begin{array}{c}1.32 \pm 0.16 \\
100\end{array}$ & $\begin{array}{c}1.40 \pm 0.11 \\
106\end{array}$ & $\begin{array}{c}1.51 \pm 0.12 \\
114\end{array}$ & $\begin{array}{c}1.57 \pm 0.10 \\
119\end{array}$ & 0.534 \\
\hline Villus area & $\begin{array}{c}0.12 \pm 0.02 \\
100\end{array}$ & $\begin{array}{c}0.18 \pm 0.01 \\
150\end{array}$ & $\begin{array}{c}0.15 \pm 0.01 \\
125\end{array}$ & $\begin{array}{c}0.19 \pm 0.03 \\
158\end{array}$ & 0.227 \\
\hline Crypt depth & $\begin{array}{c}385.83 \pm 4.16 \\
100\end{array}$ & $\begin{array}{c}330.08 \pm 60.48 \\
86\end{array}$ & $\begin{array}{c}224.76 \pm 21.62 \\
58\end{array}$ & $\begin{array}{c}270.60 \pm 24.37 \\
70\end{array}$ & 0.115 \\
\hline \multicolumn{6}{|l|}{ Jejunum } \\
\hline Villus height & $\begin{array}{c}1.21 \pm 0.15 \\
100\end{array}$ & $\begin{array}{c}1.15 \pm 0.12 \\
95\end{array}$ & $\begin{array}{c}1.15 \pm 0.09 \\
95\end{array}$ & $\begin{array}{c}1.40 \pm 0.03 \\
116\end{array}$ & 0.226 \\
\hline Villus area & $\begin{array}{c}0.14 \pm 0.04 \\
100\end{array}$ & $\begin{array}{c}0.15 \pm 0.03 \\
107\end{array}$ & $\begin{array}{c}0.14 \pm 0.01 \\
100\end{array}$ & $\begin{array}{c}0.15 \pm 0.03 \\
107\end{array}$ & 0.987 \\
\hline Crypt depth & $\begin{array}{c}216.63 \pm 29.93 \\
100\end{array}$ & $\begin{array}{c}214.49 \pm 45.51 \\
99\end{array}$ & $\begin{array}{c}186.76 \pm 14.97 \\
86\end{array}$ & $\begin{array}{c}219.86 \pm 14.06 \\
101\end{array}$ & 0.406 \\
\hline \multicolumn{6}{|l|}{ Ileum } \\
\hline Villus height & $\begin{array}{c}0.67 \pm 0.08 \\
100\end{array}$ & $\begin{array}{c}0.61 \pm 0.10 \\
91\end{array}$ & $\begin{array}{c}0.63 \pm 0.10 \\
94\end{array}$ & $\begin{array}{c}0.67 \pm 0.13 \\
100\end{array}$ & 0.757 \\
\hline Villus area & $\begin{array}{c}0.06 \pm 0.01 \\
100\end{array}$ & $\begin{array}{c}0.05 \pm 0.01 \\
83\end{array}$ & $\begin{array}{c}0.05 \pm 0.01 \\
83\end{array}$ & $\begin{array}{c}0.07 \pm 0.01 \\
117\end{array}$ & 0.103 \\
\hline Crypt depth & $\begin{array}{c}150.38 \pm 16.49 \\
100\end{array}$ & $\begin{array}{c}135.33 \pm 14.87 \\
90\end{array}$ & $\begin{array}{c}128.44 \pm 13.38 \\
85\end{array}$ & $\begin{array}{c}136.23 \pm 20.56 \\
91\end{array}$ & 0.339 \\
\hline
\end{tabular}

DFG; dried fermented ginger, FCP; fermented corncob powder.
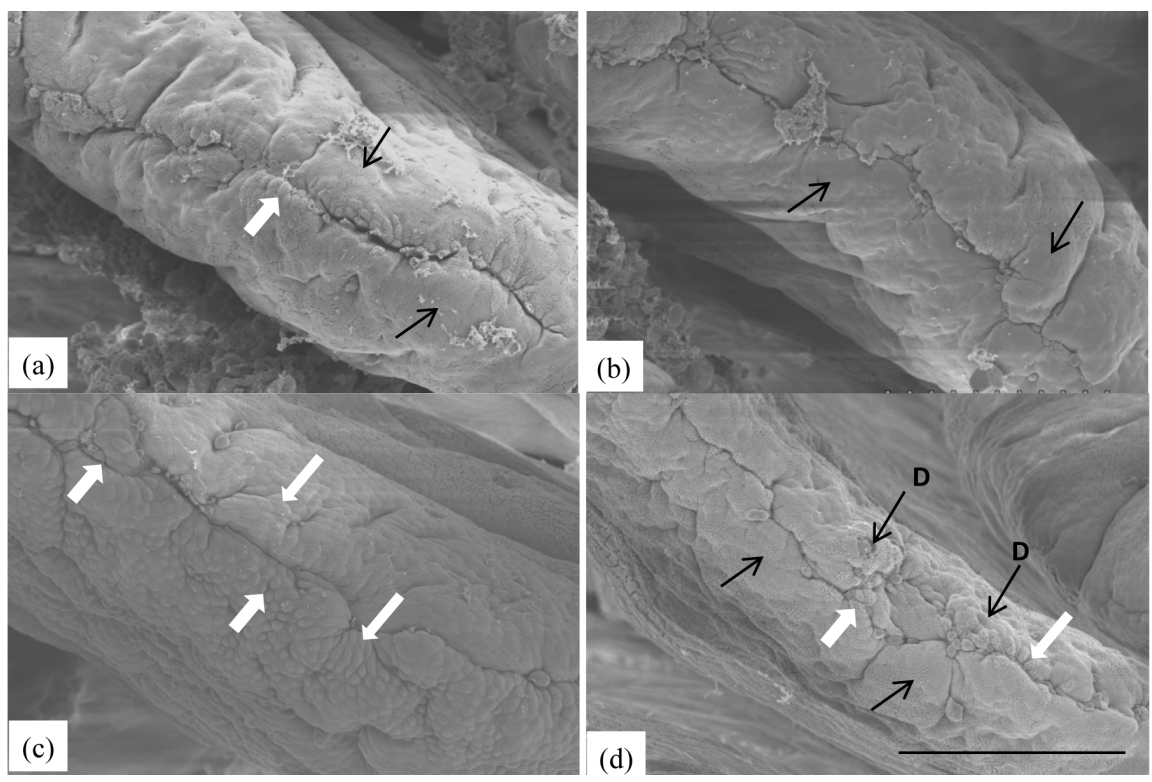

Figure 1. Duodenal villus apical surface of broilers in the basal diet group (control group; a) and in the basal diet supplemented with 50 ppm DFG (b); 50 ppm DFG +250 ppm FCP (c) and basal diet with 500 ppm FCP (d); Conventional flat cells (small arrows) develop to protuberated cells (large arrows) and deeper cells at the sites of recently exfoliated cells (arrows with d) in the 50 ppm DFG + 250 ppm FCP and 500 ppm FCP groups, suggesting functional activation. Scale bar $=100 \mu \mathrm{m}$. 

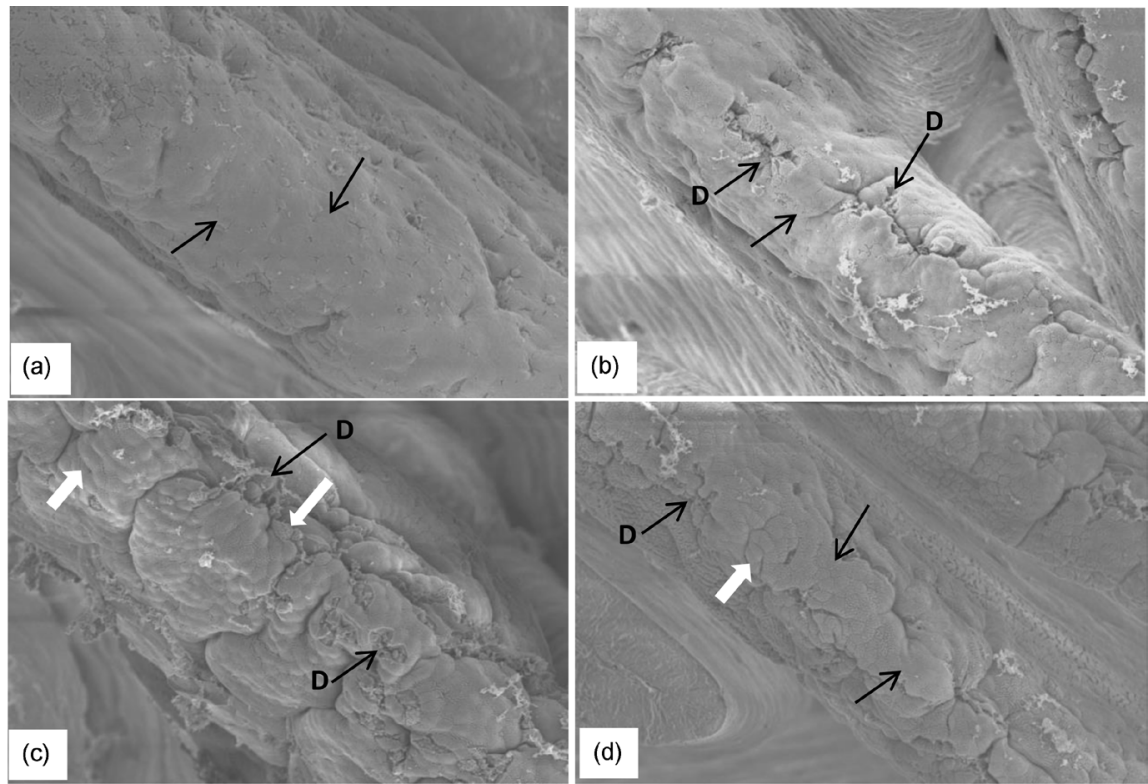

Figure 2. Jejunal villus apical surface of broilers in the basal diet group (control group; a) and in the basal diet supplemented 50 ppm DFG (b); 50 ppm DFG + 250 ppm FCP (c) and basal diet with 500 ppm FCP (d); Protuberated cells (large arrows) and deeper cells at the sites of recently exfoliated cells (arrows with $\mathrm{d}$ ) are activated than flat cells (small arrows). Scale bar $=100 \mu \mathrm{m}$.

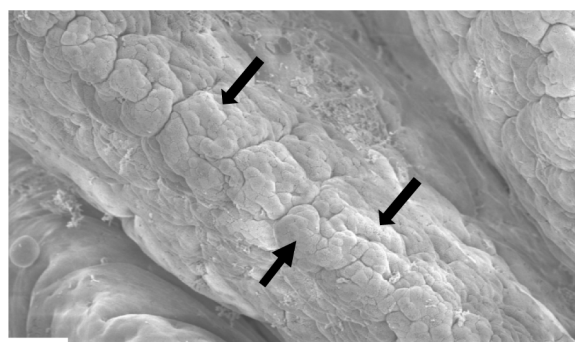

(a)

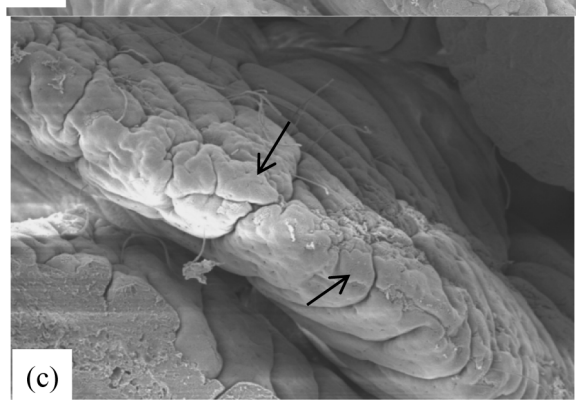

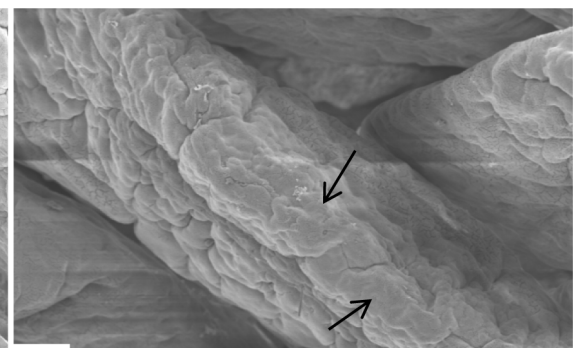

(b)

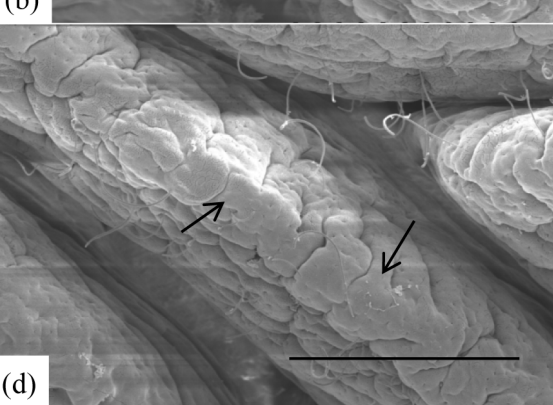

Figure 3. Ileal villus apical surface of broilers in the basal diet group (control group; a) and in the basal diet supplemented with 50 ppm DFG (b); 50 ppm DFG +250 ppm FCP (c) and basal diet with $500 \mathrm{ppm}$ FCP (d); Although the control has protuberated cell (large arrows), experimental groups show only flat cells (small arrows), suggesting no activation of experimental groups. Scale bar $=100 \mu \mathrm{m}$.

\section{Discussion}

As epithelial cells originate in the crypts by mitosis and migrate steadily toward the villus tips where cells extrude into the lumen [7], the intestinal mucosal ar- 
chitecture (morphometric alterations of intestinal villi using light microscopy as well as morphological changes of the epithelial cells on the villus apical surface using scanning electron microscopy) can be a useful index for assessing cell activity. In light microscopy, intestinal villus length and epithelial cells on the villus apical surface are known to be related to intestinal function [8]. An increased villus height is paralleled by an increased digestive and absorptive function of the intestine due to an increased absorptive surface area [9]. As longer villi allow greater absorption of the available nutrients because of their greater surface area [10], increased villus height is an indicator of an activated villus function [11]. Garlic induced lengthening of intestinal villi due to cellular hypertrophy and hyperplasia in rats [12] and broilers [13]. Sugar cane extract increased villus length in broilers [14]. The present DFG and FCP did not affect the villus height, villus area and crypt depth, suggesting that the corncob fibers did not damage the intestinal villus function. These histological results correspond with the fact that growth performance, carcass quality, and visceral organ weight did not show a significant decrease. Because of the high-fiber content in non-fermented corncob, a decreased daily body weight gain was concurrent with an increased level of corncob supplementation, due to its resistance to the pig's digestive enzymes [5]. The present morphometric values indicating no damage might be induced as a result of the fermentation of corncobs using waste JMS after DFG production; the fermentation of corncobs using rumen filtrate enhanced the crude protein value and reduced the crude fiber content [15]. In scanning electron microscopy, the protuberated cells and deeper cells at the sites of recently exfoliated cells were observed in the 50 ppm DFG +250 ppm FCP and 500 ppm FCP groups. These morphological changes in the protuberated cells [8] and in the deeper cells at the sites of recently exfoliated cells [16] are well known to indicate more activation than flat cells, suggesting that DFG and FCP can stimulate epithelial cell function at the ultrastructural level. This might be related to the presence of many kinds of nutrients in ginger, as shown in Table 2, as well as potentially bioactive constituents such as gingerols [17] (Koo et al., 2001) and shogaols [18] [19]. These substances from ginger seem to remain in JMS; as the present FCP was fermented with waste JMS after DFG production, the FCP also contains these substances. The JMS itself also includes lactic acid bacteria, yeast fungus, photosynthetic bacteria, ray fungus, hyperthermal bacteria, and Aspergillus and Bacillus subtilis [3]. These substances might become packed into the pores of the corncob, arrive in the intestine without receiving the effects of stomach acid, and flow out from the pores into the intestinal lumen, and thus might have an effect on intestinal function, resulting in the activation of the epithelial cells in the $50 \mathrm{ppm}$ DFG $+250 \mathrm{ppm}$ FCP and the 500 ppm FCP groups. The phenomenon that charcoal pores can become packed with substances was demonstrated using electron microscopy [20].

From a scientific standpoint using a statistical treatment, the growth performance and morphometric parameters of intestinal villi have no alterations. When these values are expressed as an index of 100, the experimental groups 
showed a value of 104, particularly in the body weight gain of the $50 \mathrm{ppm} \mathrm{DFG} \mathrm{+}$ $250 \mathrm{ppm}$ FCP was 106 . Within poultry production, a supplement resulting in a body weight gain of more than $2 \%$ than the control is considered effective. Regarding growth performance, although most of the percentages of the carcass, thigh, breast and wing in the experimental groups were higher than the control, the abdominal fat decreased, suggesting that the DFG and FCP affect the growth performance but suppresses fat deposition. Regarding the gross anatomical observations of the intestine and visceral organs, we could not find a difference among the groups. However, the villus height and area showed higher values in the transition from the ileum to the duodenum. This is in harmony with reports that the duodenum and initial jejunal segment absorbed lipids, while the ileum did not play a significant role in digestion or the absorption of triglycerides [21]. The duodenal crypt depth showed an extreme decrease in all experimental groups. As the crypt area is known to be a cell proliferation zone, the duodenal epithelial cells in the experimental groups do not need to multiply by cell mitosis, because the epithelial cells on the villus area were activated. This corresponds with hypertrophied cells in the duodenum and jejunum of the $50 \mathrm{ppm}$ DFG + 250 ppm FCP group as shown in the scanning electron microscopic picture. Such activation is thought to be induced by the synergistic effect of the many kinds of nutrients in ginger and the microorganisms in JMS.

In conclusion, a dietary mixture of a small amount of DFG and a small amount of FCP induced protuberated epithelial cells and deeper cells at the sites of recently exfoliated cells on the intestinal villus apical surface in the duodenum and jejunum, suggesting an activated function of the cells. This cell activation induced a $14 \%$ increase in duodenal villus height and a $24 \%$ increase in jejunal villus area, resulting in a $6 \%$ increase in body weight gain. The present results suggest that a small amount of fermented corncob powder can be used as a feed supplement when mixed with fermented ginger powder, due to their synergistic interaction.

\section{References}

[1] Hutňan, M., Špalkova, V., Bodik, I., Kolesarova, N. and Lazor, M. (2010) Biogas Production from Maize Grains and Maize Silage. Polish Journal of Environmental Studies, 19, 323-329.

[2] Muchlisyam (2014) Corn Cobs Hemicelluloses Isolation Method Comparison and its Characterization with Infra Red Spectrophotometry (FTIR) and High Performance Liquid Chromatography (HPLC). International Journal of ChemTech Research, 6, 3062-3070.

[3] Incharoen, T. and Yamauchi, K. (2009) Production Performance, Egg Quality and Intestinal Histology in Laying Hens Fed Dietary Dried Fermented Ginger. International Journal of Poultry Science, 8, 1078-1085. https://doi.org/10.3923/ijps.2009.1078.1085

[4] Incharoen, T., Yamauchi, K. and Thongwittaya, N. (2010) Intestinal Villus Histological Alterations in Broilers Fed Dietary Dried Fermented Ginger. Journal of Animal Physiology and Animal Nutrition, 94, e130-e137.

https://doi.org/10.1111/j.1439-0396.2010.00994.x 
[5] Kanengoni, A.T., Chimonyo, M., Ndimba, B.K. and Dzama, K. (2015) Potential of Using Maize Cobs in Pig Diets-A Review. Asian-Australasian Journal of Animal Sciences, 28, 1669-1679. https://doi.org/10.5713/ajas.15.0053

[6] Iji, P.A., Saki, A. and Tivey, D.R. (2001) Body and Intestinal Growth of Broiler Chicks on a Commercial Starter Diet. 1. Intestinal Weight and Mucosal Development. British Poultry Science, 42, 505-513. https://doi.org/10.1080/00071660120073151

[7] Potten, C.S. (1998) Stem Cells in Gastrointestinal Epithelium: Numbers, Characteristics and Death. Philosophical Transactions of the Royal Society B: Biological Science, 353, 821-830. https://doi.org/10.1098/rstb.1998.0246

[8] Yamauchi, K., Incharoen, T. and Yamauchi, K. (2010) The Relationship between Intestinal Histology and Function as Shown by Compensatory Enlargement of Remnant Villi after Midgut Resection in Chickens. Anatomical Record, 293, 20712079. https://doi.org/10.1002/ar.21268

[9] Amat, C., Planas, J.M. and Moreto, M. (1996) Kinetics of Hexose Uptake by the Small and Large Intestine of the Chicken. American Journal of Physiological Review, 271, 1085-1089.

[10] Caspary, W.F. (1992) Physiology and Pathophysiology of Intestinal Absorption. The American Journal of Clinical Nutrition, 55, 299S-308S.

[11] Longhout, D.J., Schutte, J.B., Van, L.P., Wiebenga, J. and Tamminga, S. (1999) Effect of Dietary High and Low Methyllated Citrus Pectin on the Activity of the Ileal Microflora and Morphology of the Small Intestine Wall of Broiler Chick. British Poultry Science, 40, 340-347. https://doi.org/10.1080/00071669987421

[12] Gupta, A. and Sandhu, R.S. (1998) Effect of Garlic Agglutinin and Garlic Extracts on the Rat Jejunum. Nutrition Research, 18, 841-850. https://doi.org/10.1016/S0271-5317(98)00069-4

[13] Abdullah, A.Y., Mahmoud, K.Z., Nusairat, B.M. and Qudsieh, R.I. (2010) Small Intestinal Histology, Production Parameters, and Meat Quality as Influenced by Dietary Supplementation of Garlic (Allium sativum) in Broiler Chicks. Italian Journal of Animal Science, 9, 414-419. https://doi.org/10.4081/ijas.2010.e80

[14] Khambualai, O., Yamauchi, K. and Ruttanavut, J. (2010) Effect of Sugar Cane Extract, Commercial Probiotic and Their Mixture on Growth Performance and Intestinal Histology in Broiler Chickens. American Journal of Animal and Veterinary Science, 5, 132-138. https://doi.org/10.3844/ajavsp.2010.132.138

[15] Adeyemi, O.A. and Familade, F.O. (2003) Replacement of Maize by Rumen Filtrate Fermented Corn-Cob in Layer Diets. Bioresource Technology, 90, 221-224.

[16] Samanya, M. and Yamauchi, K. (2001) Morphological Changes of the Intestinal Villi in Chickens Fed the Dietary Charcoal Powder Including Wood Vinegar Compounds. Journal of Poultry Science, 38, 289-301. https://doi.org/10.2141/jpsa.38.289

[17] Koo, K.L., Ammit, A.J., Tran, V.H., Duke, C.C. and Roufogalis, B.D. (2001) Gingerols and Related Analogues Inhibit Arachidonic Acid-Induced Human Platelet Serotonin Release and Aggregation. Thrombosis Research, 103, 387-397. https://doi.org/10.1016/S0049-3848(01)00338-3

[18] Chen, C., Liu, T., Liu, Y., Tseng, W., Liu, R., Lu, F., Lin, Y., Kuo, S. and Chen, C. (2007) 6-Shogaol (Alkanone from Ginger) Induces Apoptotic Cell Death of Human Hepatoma p53 Mutant Mahlavu Subline via an Oxidative Stress-Mediated Caspase-Dependent Mechanism. Journal of Agricultural and Food Chemistry, 55, 948954. https://doi.org/10.1021/jf0624594

[19] Saha, A., Blando, J., Silver, E., Beltran, L., Sessler, J. and DiGiovanni, J. (2014) 6- 
Shogaol from Dried Ginger Inhibits Growth of Prostate Cancer Cells Both in Vitro and in Vivo through Inhibition of STAT3 and NF- $\kappa$ B Signaling. Cancer Prevention Research, 7, 627-638. https://doi.org/10.1158/1940-6207.CAPR-13-0420

[20] Yamauchi, K., Manabe, N., Matsumoto, Y., Takenoyama, S. and Yamauchi, K. (2014) Increased Collagen III in Culled Chicken Meat after Feeding Dietary Wood Charcoal and Vinegar Contributes to Palatability and Tenderness. Animal Science Journal, 85, 468-480. https://doi.org/10.1111/asj.12160

[21] Wissing, S.L. and Graney, D.O. (1968) Membrane Modifications in the Apical Endocytic Complex of Ileal Epithelial Cells. Journal of Cell Biology, 39, 564-579. https://doi.org/10.1083/jcb.39.3.564

Submit or recommend next manuscript to SCIRP and we will provide best service for you:

Accepting pre-submission inquiries through Email, Facebook, LinkedIn, Twitter, etc. A wide selection of journals (inclusive of 9 subjects, more than 200 journals)

Providing 24-hour high-quality service

User-friendly online submission system

Fair and swift peer-review system

Efficient typesetting and proofreading procedure

Display of the result of downloads and visits, as well as the number of cited articles Maximum dissemination of your research work

Submit your manuscript at: http://papersubmission.scirp.org/

Or contact fns@scirp.org 